\title{
Conulariids from the Lower Ordovician of the southern Montagne Noire, France
}

Heyo Van Iten and Bertrand Lefebvre

Acta Palaeontologica Polonica 65 (3), 2020: 629-639 doi:https://doi.org/10.4202/app.00728.2020

The Tremadocian-Floian (Lower Ordovician) Saint-Chinian, La Maurerie, and Landeyran formations of the southern Montagne Noire (France) collectively contain at least two species of conulariids, namely Archaeoconularia cf. insignis and Conularia azaisi , the latter herein designated as the type species of the new genus, Galliconularia. Archaeoconularia insignis may also occur in the Lower Ordovician Fezouata Shale of southern Morocco, and an indeterminate species of this genus probably occurs in the Lower Ordovician Tonggao Formation of South China. Galliconularia azaisi differs from all other conulariids in having a raised facial midline and very fine, trochoidal transverse ribs which cross the midline ridge without interruption or diminution. In specimens preserving the outermost peridermal lamellae, the transverse ribs bear sub-microscopic nodes, and the broad interspaces are crossed by very slender interspace ridges. Finally, even though the Montagne Noire was part of the western Gondwanan passive margin during Cambro-Ordovician times, G. azaisi remains unknown outside of France.

Key words: Cnidaria, Scyphozoa, Conulariida, Paleozoic, Gondwana, Europe.

Heyo Van Iten [vaniten@ hanover.edu], Department of Geology, Hanover College, Hanover, Indiana 47243, USA and Cincinnati Museum Center, Department of Invertebrate Paleontology, 1301 Western Avenue, Cincinnati, Ohio 45203, USA. Bertrand Lefebvre [bertrand.lefebvre@univ-lyon1.fr], CNRS, UMR 5276 LGLTPE, Université Claude Bernard Lyon 1, 2 rue Dubois, F-69622 Villeurbanne, France.

This is an open-access article distributed under the terms of the Creative Commons Attribution License (for details please see creativecommons.org), which permits unrestricted use, distribution, and reproduction in any medium, provided the original author and source are credited. 
FaF 